Мр Драган Драгомировић

Универзитет у Бањој Луци

Филозофски факултет

dragan.dragomirovic@ff.unibl.org

\title{
ПЕТАР КОЧИЋ КАО (ПОСТ)КОЛОНИЈАЛНИ ПИСАЦ - ПРОБЛЕМ ПРИСТУПА
}

Кочићев живот и дјело (1877-1916) својом друштвеноисторијском условљеношћу (период смјене империјалних управа на нашим просторима) као и идеолошком подлогом (слободарски, национално и социјално освијешћен, те изразито антиимперијалистички настројен књижевни и политички рад) сугеришу могућност интерпретације у контексту теоријско-методолошких премиса постколонијалне критике. Отварајући расправу о могућностима контекстуализовања стратегија Кочићевог антиимперијалног и постколонијалног писма према појединим тенденцијама и стратегијама постколонијалног критичког дискурса покушавамо назначити и неке од проблема овако засноване интерпретације.

Кључне ријечи: Петар Кочић, постколонијална критика, постколонијална књижевност, Кочићево постколонијално писмо, стратегије отпора, теорија и методологија проучавања књижевности.

\section{Увод}

Историјско, културно и књижевно искуство српског народносног и националног ентитета на просторима Босне и Херцеговине у великој мјери формирано је у дотицајима према империјалним културама Окцидента 
и Оријента. Недвојбена је при томе српска културна утемељеност на (јужно)словенским народносним те источнохришћанским православним изворима, али и изузетно сложени културни контакти дубоког историјско-идентитетског трага са доминантним, несловенским и за Балкан неаутохтоним културама. Прије свих, турској источној османлијско-исламској те аустријској и угарској као западнохришћанским културама. ${ }^{1}$ Недвојбена је такође и чињеница да су периоди дуготрајне подређености страним културама у случају српског националног корпуса у Босни и Херцеговини праћени снажним и континуираним отпором и тежњом за ослобађањем и осамостаљењем. На конкретном и материјалном плану отпор је исказиван кроз буне и устанке, а на плану духовног и имагинарног у формама усменог и писаног памћења и документовања (в. Екмечић 2011). Упорно очување властите макар и дјелимичне политичке и вјерске аутономије пратили су напори за очувањем језика и традиције. Пут је то, судећи према доступним изворима и интерпретацијама, од колективног свјесног и колективног несвјесног, егзистенцијалног и материјалног али и легендарног и митолошког до историјског формирања српске народносне и националне свијести и менталитета. ${ }^{2}$

1 Ови дотицаји у најопштијем смислу дали би се назвати амбивалентним - у смислу сталних супротстављања и укрштања, отпора и угледање, раздвајања и раслојавања словенског народносног корпуса на југу Европе - а из контекста српске историје и културе до данашњег дана дубоко трауматичним и анксиозним.

2 Духовно-историјска интерполација феномена отпора изњедрила је и главне епове српске усмене традиције (Косовски циклус прије свих), преко средњовијековних религијских појања и записивања (в. Окука 2001), да би се пренијела и до модерних штампаних културних оруђа попут књижевности у ужем смислу - белетристике, етнографије, историографије и документаристике (Доситеј, Вук, Његош, српски романтичари и реалисти, Цвијић и др.), односно путем ширења организованог образовног система у 19. и 20. вијеку. 
Данас би се све то, у теоријском смислу, могло назвати и различитим културним стратегијама отпора док се контактна искуства (укрштања, хегемонија и израбљивање, отпор, формирање идентитета) посматрана са тежиштем на опису политика експлоатације и стратегија отпора, обично фиксирају као суштинска обиљежја појмовних синтагми антиколонијално и постколонијално стање, књижевност, критика. Узимајући у обзир чињенице које нам нуде дискурси српске књижевности, опште националне историје те књижевне историје и теорије, под појмовима антиколонијалног и постколонијалног могла би се анализирати и нека од главних обиљежја у формирању српског културног идентитета Босне и Херцеговине нарочито у периоду краја 19. и почетка 20. вијека - динамичном периоду смјене империја у Босни. Имајући на уму западноевропску епистемолошку утемељеност, терминолошку и темпоралну нестабилност појмовља са предзнаком йосйколонијалної потребно је, у српском културном и кочићевском контексту, мислити прије свега о његовим најважнијим субверзивним аспектима - субверзивим према политикама културне и духовне колонизације.

Постколонијална књижевност и Петар Кочић

Уско терминолошки гледано сам израз постколонијална књижевност и критика готово да сасвим обухвата појмове колонијалне књижевности, постколонијалне књижевности али у коначници и неоколонијалне књижевности и критике. У том смислу под постколонијалну књижевност и критику подводе се готово сви књижевни текстови који представљају реакцију на дискурс колонизације. Темпорално-квантитативна димензија појма потиснута је на рачун квалитативне димензије којој су 
заједничке управо континуиране тенденције економске, политичке и културне доминације западног цивилизацијског круга над остатком човјечанства те њени продукти и посљедице. ${ }^{3}$ Стога је можда и разумљива чињеница непостојања јединствене теорије и методологије постколонијалне критике као и то да је свим варијантама овог приступа заједничка интенција „оспоравање представа које су колонизатори створили о колонизованим културама“. Нека од суштинских обиљежја овог књижевно-културолошког истраживачког дискурса јесу и та да „проучава и стварање новог специфичног дискурса, обликованог да ту представу раскринка као и да пружи отпор даљем наметању евро-америчке културне хегемоније у бившим колонијама“ као и да „сагледају механизме успостављања националних идентитета и да сагледају

Много је још увијек отворених расправа у вези са термином йосйколонијално али у најкрупнијим цртама овај термин „понекад се примењује на земље које још увек нису оствариле независност, или на деколонизоване народе потпале под неоколонијални утицај капитализма и глобализације; може да се односи и на мањине на западу или на источноевропске државе које су некада биле део великих империја (Отоманског царства, Аустроугарске, Совјетског Савеза)“ (Гвозден 2011: 305). Поред тога и проучавање текстова незападњака о односу колонијалних и империјалних сила према подређеним културама, језицима и народима сврстава се сасвим равноправно у постколонијалну књижевност и критику. Отуда се за постколонијалну књижевност сматра и књижевност народа и нација која настаје у периоду и процесу рушења класичних империјалних система, интензивног деколонизовања након Првог и Другог свјетског рата и тиче се, прије свега, народа и култура које су трајно и пресудно обиљежене француским и англо-америчким колонијализмом (в. Aschroft, Griffiths i Tiffin 2002). 
Петар Кочић као (пост)колонијални писац - проблем... 163

делатност писаца колонизованих земаља који стварају сопствени културни идентитет, кроз одбацивање или поништавање утицаја колонизатора“" (Popović 2007: 556).

Културе колонизованих народа опустошене материјално и духовно, културе су то прогутаних и збрисаних аутохтоних језика, људских и материјалних ресурса. Културе које су коначно проговориле и стекле право гласа тек у 19. и 20. вијеку преко својих представника школованих у западним метрополама, антиколонијалних писаца. Прави значај постколонијалне критике лежи у томе што је то у протекле двије деценије најпродуктивнији културолошко-књижевни истраживачки дискурс који, најопштије гледано, скреће пажњу на парадоксалну и безизлазну позицију Европе и западног друштва као цивилизацијски номинално водеће културе (в. Eagleton 2005). Постколонијална критика, када је заиста критика, упозорава на историјско-политичко и материјално утемељење Европе на класном разликовању, опљачканим природним и људским ресурсима без помисли о прихватању одговорности, као и на културно утемељење Европе на другости незападњака, стереотипима о нецивилизованим, варварима, мање вриједних људи, ближим звјерима него људском роду (Sezer 2015; Fanon 1973, Меми 2015). У крајњој линији, полажући ексклузивно право на дискурсе филозофије, историје и књижевности, на поимање етике и естетике, западни човјек негира могућност и саме помисли на властиту одговорност у глобалном и историјском контексту, фалсификујући на тај начин не само заједничку прошлост него и будућност човјечанства.

Иако је своје пуно утврђивање и афирмацију доживјела на западним катедрама компаративне књижевности преко радова Едварда В. Саида, Гајатри Чакраворти Спивак и Хомија Бабе, мишљења смо да је и данас најпотицајнији дио постколонијализма као критичке дјелатности онај који припада такозваној колонијалној и постколонијалној књижевности, заправо књижевност 
колонизованих аутохтоних народа (азијских, афричких, карипских, јужноамеричких и др.). Иницирање и освјештавање потекло је управо од писаца револуционара почев од индијског филозофа и државника Махатме Гандија, Хозеа Мартија са Кубе, Мартиничанина Емеа Сезера и Франца Фанона, Кенијца Нгугија ва Тионга, Нигеријца Чинуе Ачибеа и бројних других. Све су то имена која активно, списатељски и политички заступају политике потпуне деколонизације својих народа и земаља и Кочић би се, у најширем смислу дао поредити с њима, и тако већ на контекстуалном или спољашњем плану, могао назвати антиколонијалним и постколонијалним писцем.

Јасно је да када говоримо о могућности отпора империјализму разлика је у положају, третману и ипак повољнијим условима борбе коју остварују европски па тако и српски народ у односу на аутохтоне афричке, азијске, сјевероамеричке и јужноамеричке народе. Конституисање модерних европских нација и држава, попут италијанског или чешког и словачког ослобађања од аустроугарског империјалног утицаја, идеја и напора српског народа за ослобођењем, коначно и Француске револуције која их је потакнула, донедавне ирске борбе за ослобођење од енглеског колонијализма, све су то примјери дјеловања деветнаестовијековне идеје о самосталности нација и језика, суверенитету модерних националних држава и народа, идеја субверзивног исхода које су потакле револуционисање и модернизовање друштвених уређења. Након рушења класичних империја у Првом и Другом свјетском рату идеје националне државности, суверенитета и самосталности више нису могле бити оспораване ни народима такозваног трећег свијета. Као што примјећује Сретен Божић, Први српски устанак 1804. године можда је и први антиколонијални устанак у модерној историји (Вонгар 2010), а свакако је водиља Србима у Босни и Херцеговини који су вијек 
дуже до своје сабраће у Србији остали под влашћу страних империја. ${ }^{4}$ Кочићев профил писца са периферије империја, из земље нетом пребачене из вијековне турске окупације под протекторат Аустроугарске монархије, а школованог у Бечу у средишту империје, сасвим је у дослуху са историјско-друштвеним тенденцијама тога времена. Стратегије отпора обиљежене директним политичким ангажманом али и директним литерарним говором о проблемима порабоченог народа појачавају значај овакве компарације ситуирајући Кочића за једног од најзначајнијих антиколонијалнијих и антиимперијалних писаца и једног од претеча потоњег постколонијалног писма - књижевности и критике.

Кочић отписује империјама

Много пута је примијећено да рад Петра Кочића као ријетко чији други одликује готово досљедно подударање политичке и књижевне активности као што је и потврђена јасна представа о њему као националном писцу и трибуну из периода заласка империјалних царстава (в. Скерлић 1964, Чубриловић 2016, Вулин 1990, Вулин 2001, Милановић 2011). Цјелокупан Кочићев литерарни, политички, духовни и практични ангажман извирао је из његове борбе против двију обесправљености српског народа: социјалне и националне обесправљености при чему Кочић готово да поистовјећује ова два плана. Разумљиво је то с обзиром на подређени положај у којем се налазио српски православни сељачки живаљ у то доба, из којег је и сам Кочић потицао и са којим се до посљедњих година живота сасвим идентификовао. Не одричући се

4 Устанак робова на Хаитију против француске колонијалне управе, започет у посљедњој деценији 18. вијека, завршава свој најкрвавији период проглашењем независности Сен Домингеа 1. јануара 1804. године. 
властитог сељачког поријекла нити у јавном дискурсу нити у умјетничкој литератури Кочићев национализам је демократске и егалитаристичке провенијенције. Чини се заправо да је за њега класна подјела и неједнакост далеко важнији и већи проблем од народносне или религијске подјеле. ${ }^{5}$ Кочићева интересовања крећу се у распону од аграрног (кметовског) питања, експлоатације шума, националног језика и образовања изражених у његовом политичком и публицистичком раду, преко умјетничке транспозиције тешке босанскохерцеговачке реалности у оригиналном књижевном дјелу. Ситуирано у период смјене источне турске и западне аустроугарске хегемоније на нашим просторима, својом бунтовничком и субверзивном природом готово да је парадигматичан примјер антиколонијалног и постколонијалног писма и писања. При томе треба имати на уму да је Кочићева академска култура, као уосталом и код већине српских интелектуалаца његовог времена, западњачке провенијенције. ${ }^{6}$ Отуда је и Кочићева критика аустроугарске

5 Отуда и његова отвореност за потенцијално прихватање идеје југословенске заједнице као националне идеје уколико би она водила коначном ослобођењу од страних утицаја и рушењу класно заснованог друштвеног система исказана у политичким говорима и интерпелацијама (в. Кочић 2002в).

6 Кочић се одушевљава научним методом Јован Цвијића и поштује интерес за науку и етнографију осамдесетих година 19. вијека. Презире стихоклепце деведесетих. Отуда можда и његов реализам у књижевности, а након разочарања и лоших критика његових почетничких покушаја у поезији. Социјално и национално освјешћен промовише српски национализам али се ослања и на идеје заједништва јужнословенских народа без обзира на вјерску припадност. Социјалне слободе и правда су испред националних идеја, ако их је уопште могуће раздвојити у овом историјском периоду у којем је српска сељачка популација покушавала скинути бреме кметства под Турцима замијењено ропством под Аустроугарима, док је српска малобројнија грађанско-трговачка или бирократска 
политике и администрације изузетно самосвјесна, прецизна и оштра, и са данашњих позиција гледано сасвим легитимна. Кочићев Давид Штрбац примјећује како ће синови монархије након школовања у њеном средишту у такозваним терезијанским школама бити способни да униште монархију када „поприме вашу учевину, списе и протокуре“ (Кочић 2002б: 95). Недвојбена је дакле Кочићева пуна свијест о положају, интелектуалном и политичком путу и задатку који је пред себе поставио што је још један разлог за постављање паралеле између Кочића и главних критичара и бораца против колонијализма у другим крајевима свијета и могућност расправе о Кочићу као постколонијалном писцу.

Оно што писце попут Петра Кочића и српску књижевност у Босни и Херцеговини у највећој мјери разликује од постколонијалних писаца обиљежених енглеским и француским колонијализмима јесте у потпуности сачувана способност и и могућност говора на матерњем и аутохтоном језику. Специфичан културно-историјски контекст који је условио појаву вјерско-религијског диференцирања српског народносног и језичког тијела довео је и до сасвим вјештачког и политичког вишеструког именовања тог једног аутохтоног и заједничког

популација конформистички реаговала на овакве покрете. Православни сељаци, Кочићу управо најближи, били су поново „колонизовани“ и најугроженији живаљ у Босни и Херцеговини за разлику од муслиманског „племства“ или католичког становништва али и српских трговаца, администрације и корумпиране политичке и градске елите која се конституише у новим оквирима посљедњих деценија 19. и на почетку 20. вијека. Касни феудализам отоманског типа са свим специфичностима босанскохерцеговачког историјског и културног контекста замијенио је не много, ако ишта, хуманији капитализам аустроугарског монархијског типа. Поред политичких чланака о томе говоре и Кочићеве лирске суданије, забиљешке и чланци (в. Кочић 2002а; Кочић 20026). 
језика, али, до глотофагије, у смислу потпуног преузимања језичког простора од стране турске, германске или угарске империје није дошло. (О глотофагији и трагичним посљедицама исте в. Kalve 1981; Ngugi wa Thiongo 1994.) Неки од разлога оваквом развоју догађаја свакако су и константни устанци и буне за ослобођење, самосталност и аутономију српског народа, односно стална материјална и духовна интенција српског колективитета за ослобађањем од потлачености и подређености османским, а потом и аустроугарским империјалним системима. У модерно доба упоредо је текао и једнако важан процес конструисања властите националне идеологије и одржавања слике свијета засноване на искуству националне и социјалне подређености, а сасвим у дослуху са националним идеологијама европског романтичарског 19. вијека - токови у које је српска култура директно упловила путем рада Вука Караџића и његових насљедника.?

Главне Кочићеве политичке и списатељске преокупације су све општа „колонијска порабоћеност и подврженост“ (Кочић 20026: 291), при чему наш писац као примарну види конкретну политичку борбу за ослобађање кметова из ропског статуса која је тек дјелимично уродила плодом у другој деценији 20. вијека. Ишчитавамо то једнако у политичким и програмским текстовима као и у главним књижевноумјетничким дјелима Кочићевим.

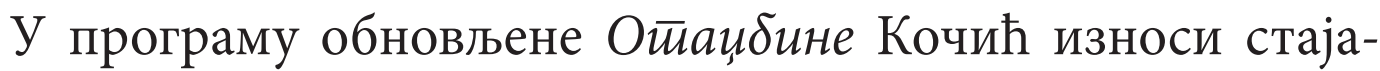
лиште које је изразито гласно заступао као посланик у Босанском сабору да „Обавезни откуп кметова, који би

7 Примијетимо како питање за нас, дакле, не може бити оно Спивакино из описа енглеско-индијских колонијалних односа односно енглеске хегемоније над „Индијама“, о двоструко подређеним Индијкама које гласи „могу ли подређени да говоре“ (Spivak 2011) већ колико гласно подређени могу да говоре. Кочић је то сликовито изрекао синтагмом „јауци са Змијања“. 
узела држава у своје руке, сматрамо јединим правилним рјешењем овога животног питања за све слојеве народа и за саму државу.“ (Кочић 2002б: 364). Тадашња босанска скупштина је усвојила приједлог закона о факултативном откупу робова/кметова који је, на Кочићево велико разочарање, подржао и српски клуб у Сабору. Неколико

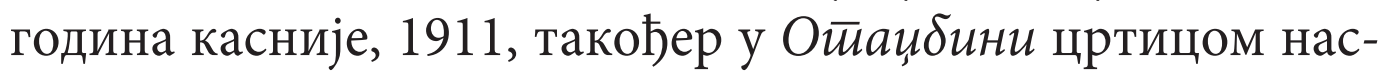
ловљеном „Кмети“ Кочић оставља потресно свједочење о колонијалној историји и стварности Босне:

„Узаман су надања, јалова су и празна очекивања наша, видимо ми. Вијекови пролазе, цареви се на Босни мијењају, а ми, проклетници и мученици, једнако робујемо и кметујемо [...] понижени до скота [...] Ми свијетла дана немамо, ми мирне ноћи немамо! И оне горске звијери имају гдје мирно склонити главу, а ми, убоги, немамо сигурна станишта и стојбине. Хитри ловци с пушкама у руци прогоне горске звијери, а нас људи с царскијем законом у руци гоне с кућишта предака нашијех. Ми смо ти, што но веле, незаробљено робље једно: код куће а без куће, код земље а без земље, код постојбине а без постојбине. Ми свијетла дана немамо, ми мирне ноћи немамо!“ (Кочић 20026: 69-70)

Као што је готово немогуће одвојити његов литерарни од политичког рада тако је и Кочићева свијест о неопходности очувања српског језика нераздвојна од свијести о кметском питању, питању слободе аутохтоног народа и становништва у Босни и Херцеговини. У својим ставовима о политичкој, материјалној, културној и духовној порабоћености српског сељака у тадашњим аустроугарским провинцијама Босни и Херцеговини, Кочић је крајње директан. Јасан је и отворен до те мјере да су царски бирократски херменеутичари без муке препознавали опасност по колонијално устројство државног система о чему најбоље свједоче прописане затворске 


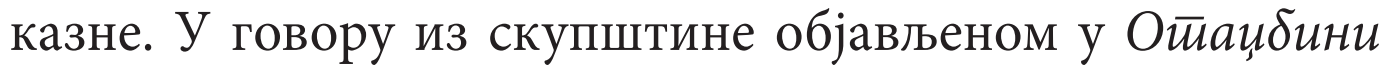
1911. Кочић изјављује:

„ऍев нас обузима што и у том унакажавању и мрцварењу нашег сјајног и слободног језика осјећамо своју све-

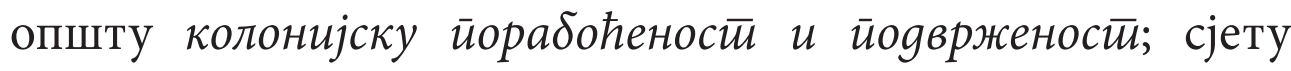
дубоку у души носимо што смо слаби и немоћни да заштитимо од профанисања и обесвећења свој велики и силни језик.“ (Кочић 2002б: 291, подвукао Д. Д.)

О Кочићевом поистовјећивању права на властити језик и говор са личном и колективном слободом говори његова лирска проза Молийва у којој се могућност ослобађања из несрећног ропског положаја поистовјећује са могућношћу говора подређених. У Молитиви језик поприма метафизичке димензије да би га само народ којем припада разумио те да би на тај начин био ослобођен колонијалних стега и на елементарној комуникацијској и контактној равни. Кочићево искуство колонијализма свједочи потпуни песимизам у погледу могућности хуманијег сусрета западних, технички доминантних са незападним потцијењеним народима и културама. И што је можда још значајније, Молийва доноси Кочићеве увиде у дубину и размјере духовног, умног и идентитетског колонизовања које почиње и завршава на границама језика. ${ }^{8}$

„Несрећан си, Народе мој, биједна си, Отаџбино моја! Знам ја и осјећам невоље твоје и црни чемер што ти је стегао душу твоју [...] О боже мој велики и силни и недостижни, дај ми језик, дај ми крупне и големе ријечи које душмани не разумију а народ разумије [...] Дај ми те ријечи и обдари ме, господе мој, тијем даром својијем великијем и милошћу својом

8 Ријеч је о сасвим реалној опасности од губљења властитог језика и идентитета коју нису имали снаге и среће да избјегну аутохтони народи широм планете, од сјеверноамеричког континента до Аустралије (в. Вонгар 2010; Ngugi wa Thiongo 1994). 
неизмјерном, јер ће ми срце свенути, јер ће ми се душа од превелике туге и жалости разгубати!“ (Кочић 20026: 60-61)

Кочићево постколонијалног писмо, субверзивно оријентисано према политици аустријске управе, на директан али и ироничан начин проказује доминантни идеолошки дискурс и тадашњу увријежену бирократску праксу. Стратегије отпора које је могуће ишчитати у његовим текстовима недвосмислено разарају и изврћу руглу главне принципе аустријске империјалне политике и управе у Босни утврђујући дугорочне претпоставке за будуће ослобођење и самосталност коју Кочић неће доживјети. Једнаког су антиколонијалног и слободарског усмјерења Кочићеви ставови објављивани у кратким цртицама, попут Тежака из првог броја Ойацбине 1907. године, због које је Кочић осуђен на робију:

„У стари земан, за турског суда и турске, да кажемо, суданије, могло се некако живкарити и прометати [...] а откад заступи ова проклета и црна укопација, налет је било, све нас у црно зави. Бијели некакви људи у црној ођећи и црним шкрљацима размиљеше се као мрави по земљи нашој и отроваше нам и земљу и живот [...] а у људе уђе некакво проклетство и невјерлук.“ (Кочић 20026: 57)

Кочић отписује империји ругајући се нељудскости аустријског бирократског система, називајући га горим од претходне вишевијековне хегемоније Османлија. Сатиричним примједбама Кочић деградира и руши легитимитет аустријске колонијалне хегемоније над српским живљем и земљом у Босни и Херцеговини. Са османлијским властима се путем изабраних представника могло преговарати и изборити за олакшања и повластице, примјећује на много мјеста Кочић, са зорли кабасиичм йалиірайима нема разговора. 
Своје постколонијално писмо у књижевном дјелу Кочић гради гласовима својих јунака (Давида Штрпца, Мрачајског Проте, Симеуна Ђака, Малог Лује), гласовима потлачених, стијешњених и угњетаних личности и колективитета, потом и вишеслојним комплексним захватом у тадашњу друштвену, политичку, духовну и културну стварност анексиране Босне и Херцеговине. Било да је ријеч о лирској прози, кратким причама, суданијама или драмском језику, Кочић разоткрива проблеме савременог социјално-експлоататорског дискурса потенцирајући културно-историјску и духовну самосвијест српског народа Крајине и Босне. Директно разарање аустроугарског политичког дискурса у књижевности ишчитавамо у Јазавиу йреg суgом у којем је највидљивије можда и кључно обиљежје Кочићевог постколонијалног писма, његов иронично-сатирични отпор глотофагији и културофагији. Језичким играма, хумором и сатиром, сучељавањем језика и природне логике неуког аутохтоног човјека према вјештачким силама колонијалног бирократског система, Кочић ослобађа субверзивне потенцијале књижевног текста засијецајући у саму срж неправедне колонијалне босанске стварности. Његово књижевноумјетничко писмо, посматрано у цјелини, изграђено је на психолошким димензијама угрожености обичног човјека, компаративним увидима у смјене империја, епско-историјској, јуначкој и побуњеничкој етици, идејама једнакоправности народа и религија. Са историјске перспективе гледано Кочићево постколонијално писмо у свим својим елементима утиче на књижевно и културно утврђивање, конституисање самосвијести о властитом националном, језичком и културном идентитету, што је можда најважније наслијеђе цјелокупној српској култури, њеном очувању у скрбним и бесудним временима којима се још не види крај. Није стога без разлога Кочић био један од омиљених писаца револуционарне омладине окупљене око Младе Босне. 
Петар Кочић као (пост)колонијални писац - проблем... 173

Постколонијални, антиимперијални или једноставно Кочић

Шири аспект наших интересовања који смо овим радом тек назначили тиче се, најкраће говорећи, не само могућности него и потребе за интерпретацијом Кочићевог списатељског дјела са позиција савременог књижевно-теоријског и културолошког приступа познатог под именом постколонијалне критике. Занимају нас, у најширим потезима гледано, могућности успостављања аналитичке апаратуре преко неких од главних критичких премиса постколонијалне критике, схваћене као контекстуално или традиционалним рјечником говорећи вањско проучавање књижевности и схваћене као историјски заснован књижевни и културолошки приступ којим се инсистира на преиспитивању, разоткривању и деконструисању начина на који је, прије свега, доминантна западњачка империјалистичка и колонијалистичка култура и идеологија подређивала све друге културе с којима је била у дотицају.

Потребно је при томе бити свјестан поетичких и политичких премиса али и историјског контекста анексиране и поробљене земље која је и према својој географској позицији као и језичкој, политичкој и културној историји европске провенијенције и не може се сасвим експлицитно и недвосмислено назвати колонијом. С обзиром на чињеницу да вијекови империјалних управа и страних владавина нису успјели да сломе културу и осјећање националне припадности српског народа у Босни и Херцеговини, а имајући на уму значај књижевног и културног рада, пред нама се отвара још једно запажање. Могли бисмо заправо рећи, из књижевно-научне перспективе гледано, како се значај културног, језичког (усменог и писаног) ситуирања и формирање самосвијести указују као пресудан, у смислу обављања предрадњи 
и предуслова за институционало, државно и национално организовање и деколонизовање.

Постколонијалним читањем Кочића српски национални писац бива контекстуализован у опште оквире књижевних проучавања доприносећи расвјетљавању и допуњавању широке слике књижевно-историјских и културних односа империјалних сила и њихових доминиона. Кочића све то сврстава у низ писаца-бораца за хуманије и слободно друштво не само у оквирима националне историје књижевности него и књижевно-историјских и хуманистичких изучавања на глобалном плану. Универзалне естетске, поетичке и хуманистичке вриједности западне културе, парадоксално али истинито, задржавају ексклузивно право на универзализам и нормирање вриједности у домену искључиво западних књижевности, језика и култура. Остале, периферне, културе и књижевности такозваног трећег и другог свијета, па и словенске културе у тако конструисаној констелацији сада већ традиционалној, нижег су ранга и њихово вредновање засновано је на степену опонашања универзалних западних поетичких, стилистичких, па и идеолошких модела. Мишљења смо да је неопходно њено деконструисање поновним ишчитавањем и наших антиколонијалних писаца. Стратегије политичког и књижевно-умјетничког отпора које ишчитавамо у Кочићевом постколонијалном писму чине се да су још увијек имуне на сталне модификације колонијалистичког дискурса које по правилу воде новим моделима културног колонизовања потичући готово по правилу феномен аутоколонизовања.

Закључимо како је, с једне стране, ово покушај нешто другачијег и актуелизованог приступа увелико истраженом Кочићевом дјелу, а са друге стране, конципирање критичког приступа теоријско-методолошким премисама постколонијалне критике са аспекта српске књижевности и културе. У позадини свега тога лежи сасвим субјективна 
и пристрасна запитаност: може ли поновно ишчитавање Кочићевог дјела, које је засновано на високом степену нелагоде према фразерству и пуком величању лика и дјела доказаног националног писца, допринијети ревитализовању презасићеног и исцрпљеног критичког дискурса? Може ли писање са периферије и овај пут, као што то бијаше случај са Сезером и Фаноном, унијети макар мало свјетлости у центар и његово империјално срце таме?

Зашто би овакав приступ нама данас био важан? Упоредимо ли контекст Кочићевог времена обиљеженог смјенама империјалних хегемонија и наше данашње протекторате и такозване државне, економске, а тиме и националне и културне суверенитете, неминовно излазимо пред питање „могу ли подређени заиста да говоре?" и ко то данас говори у наше име, било језиком књижевности, умјетности или политике? Имајући на уму да је савремени неоимперијалистички политички, друштвени и културни контекст дубоко детерминисан процесима унификације и глобализације култура који теже поништавању културних различитости, критичко опсервирање најснажнијих методолошких стремљења англо-америчке књижевно-културолошке парадигме чини се данас више него неодложан посао. У том смислу аналогије између наше стварности и Кочићевог доба су толико очигледне да их једноставно не можемо игнорисати.

\section{Извори и литература}

Aschroft, Bill, Griffiths, Gareth, Tiffin, Helen. The Empire Writes

Back. Theory and practice in post-colonial literatures. $2^{\text {nd }}$ edition. London-New York: Routledge, 2002.

Eagleton, Terry. Teorija i nakon nje. Zagreb: Algoritam, 2005. Fanon, Frantz. Prezreni na svijetu. Zagreb: Stvarnost, 1973. 
Вонгар, Б. Дині̄ово леїло. Београд. Јасен, 2010.

Вулин, Миодраг М. Пет̄ар Кочић - йисаи и gело. Сарајево: Свјетлост, 1990.

Вулин, Миодраг М. „Визија слободе и аутономије Змијања и змијањаца - од кнеза Ратка до Кочића и наших дана“. У: Филозофско-филолочке науке на йочейку 21. вијека - ирродлеми и ирравиц развоја Бања Лука: Филозофски факултет, 2001, 77-114.

Гвозден, Владимир. „Постколонијалне студије“. У: Преітлеgни

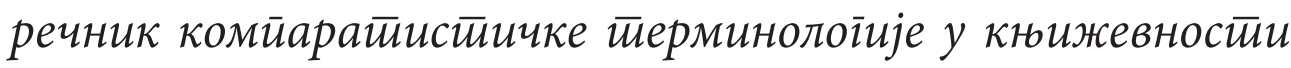
u кулитури. Ур. Бојана Стојановић Пантовић, Миодраг Радовић, Владимир Гвозден. Нови Сад: Академска књига, 2011, 305-308.

Екмечић, Милорад. Дуіо крейане између клана и орағьа. Истиорија Срба у новом веку (1492-1992), четврто издање, Београд: Евро-Ђунти, 2011.

Kalve, Luj-Žan. Lingvistika i kolonijalizam. Beograd: Biblioteka XX vek, 1981.

Кочић, Петар. Сабрана gјела 1. Бања Лука: Бесједа; Београд: Ars Libri, 2002a

Кочић, Петар. Сабрана gјела 2. Бања Лука: Бесједа; Београд: Ars Libri, 20026

Кочић, Петар. Сабрана gјела 3. Бања Лука: Бесједа; Београд: Ars Libri, 2002в

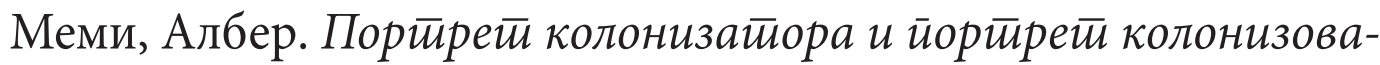
ної. Вишеград: Андрићев институт, 2015.

Милановић, Бранко. Сӣуgије из срииске къижевностии (Све-

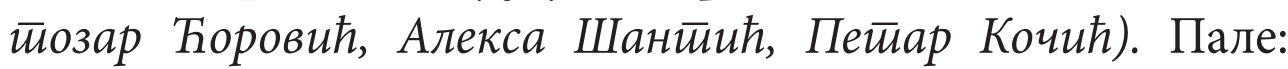
Српско просвјетно и културно друштво „Просвјета“, 2011. Ngugi wa Thiongo. Decolonising the Mind. The Politics of Language in African Literature. Harare: Zimbabwe Publishing House,1994.

Окука, Милош. Добра земльо шайни кроз зїъечене влайи (Срйска кюижевносии Босне и Хериеїовине оg Љубавића̂ gо gанас). Бања Лука - Београд: Задужбина Петар Кочић, 2001.

Popović, Tanja. Rečnik književnih termina. Beograd: Logos Art, 2007. Sezer, Eme. Rasprava o kolonijalizmu. Beograd: Fakultet za medije i komunikacije, 2015. 
Скерлић, Јован. Писии и кюиіе, Сабрана дела, књ. 5. Београд: Просвета, 1964.

Spivak, Gayatri Chakravorty. „Mogu li podređeni da govore“. Nacionalizam i imaginacija i drugi eseji. Zagreb: Fraktura, 2011. Чубриловић, Бранко. Пейар Кочић и юеі̄ово gоба. Репринт издање. Бања Лука - Београд: Задужбина Петар Кочић, 2016.

\section{Dragan Dragomirović}

\section{PETAR KOČIĆ AS (POST) COLONIAL WRITER - THE PROBLEM OF APPROACH}

\section{Summary}

The expansion of the postcolonial critique of the current most dominant literary-critical complex - Anglo-American, and its insistence on the contextual analysis of the text, its transformation from, we believe, the political reading to the reading of the policies, as well as the position of Serbian literature and culture as a place "between East and West" indicate the need to review this critical discourse with our position. The life and work of Petar Kočić (18771916) with its socio-historical conditionality (shifts of imperial administrations in our region) and its ideological background (libertarian and extremely anti-colonial minded literary and political work) provide an opportunity to attempt to interpret in the context of methodological premises of the so-called postcolonial criticism and theory. In our work we try to merely indicate some of the theoretical and methodological problems like based interpretation. More specifically, the question arises: to what extent and in what way it is possible Petar Kočić to be seen as a (post) colonial writer and what are the possible consequences of this kind of approach? Is contemporary postcolonial critique acceptable as an interpretative model of Serbian literature and culture? Considering that modern neo-imperialist political, social and cultural context is deeply marked by the processes of globalization of culture and 
unification that seek annulment of cultural difference, critical positioning towards the strongest methodological tendencies of the Anglo-American literary and cultural paradigms today seems more than a pressing task. In this sense, the analogy between our reality and Kočić act is too obvious that we can't simply ignore it.

Key words: Petar Kočić, postcolonial criticism, postcolonial literature, Kočić's postcolonial writing, resistance strategy, theory and methodology of literature study. 